\title{
THE ROLE OF ARBUSCULAR MYCORRHIZA IN PROTECTION OF Kalanchoe blossfeldiana PLANTS AGAINST HEAVY METAL TOXICITY IN SEWAGE WATER CONTAMINATED SOIL
}

Asrar, A. A.

Plant production Department, College of Food and Agriculture Sciences, King Saud University, Riaydh, P.O. Box 2460, Riyadh 11451, Saudi Arabia

\begin{abstract}
The effects of an arbuscular mycorrhizal (AM) fungus (Glomus constrictum Trappe) on the growth, flower yield, relative chlorophyll content and some minerals and heavy metal contents of Kalanchoe (Kalanchoe biossfeldiana Poelin) plants grown in sterilized soil irrigated with different concentrations of sewage water were studied. Application of sewage water significantly reduced growth responses, flower parameters, mineral contents, and levels of mycorrhizal colonization of mycorrhizal and non-mycorrhizal Kalanchoe plants as compared to control untreated plants particularly at high concentrations, but the rate of reduction was more pronounced in non-mycorrhizal treatments. Mycorrhizal Kalanchoe plants had significantly higher biomass, plant heights, leaf area, relative chlorophyll content, flower yield and nutrient $(\mathrm{P}, \mathrm{N}, \mathrm{K}$ and $\mathrm{Mg}$ ) contents comparing to those non-mycorrhizal plants irrigated with or without sewage water conditions. Under sewage water application, the AM colonization had greatly reduced heavy metal $(\mathrm{Zn}, \mathrm{Co}, \mathrm{Mn}, \mathrm{Cu})$ contents in the shoot and root tissues of the Kalanchoe plants as compared to equivalent non-mycorrhizal plants. This study shows that growing Kalanchoe with AM inoculum can minimize heavy metals toxicity and increase growth, flower yield and $P$ uptake. In this regard, the AM fungi have a protective role for the host plant, thus playing important role in soil contaminant immobilization processes, therefore, are of value in phytoremediation of heavy metals in sewage water contaminated soil.

Keywords: Arbuscular mycorrhizal, Heavy metals, Growth responses, Kalanchoe biossfeldiana, flower yield, Phytoremediation, sewage water contaminated soil
\end{abstract}

\section{INTRODUCTION}

Sewage water used for irrigation of cultivated soils in Saudi Arabia can lead in turn to accumulate of some elements like heavy metals in growing plants. These elements are strongly toxic to crops, horticulture and vegetable plants. Heavy metal contamination of soil poses serious environmental and health problems and requires technological solutions for mitigating potential environmental risks. Contrast to the traditional remediation methods for contaminated soils, bioremediation is an economically non-destructive approach (Huang et al., 2002; Tang et al., 2009). Bioremediation is defined as the use of biological systems to clean up contaminated environments. The ultimate goal of bioremediation research, whether under laboratory or field conditions, is the restoration of polluted ecosystem and it is equally important to examine the environmental fate and direct effects of contaminants on plant 
Asrar, A. A.

systems (Schutzenduble and Polle, 2002). Arbuscular mycorrhizal (AM) fungi are important components of soil phytoremediation in terms of increasing plant growth and nutrient uptake (Abdel-Fattah and Rabie, 1985; Shen et al., 2006; Wang et al., 2008; Rashid et al., 2009; Tang et al., 2009).

Arbuscular mycorrhizal (AM) fungi can form potentially beneficial associations with the roots of more than $90 \%$ of terrestrial plant species (Smith and Smith, 1979, Abdel-Fattah et al., 2009). AM has proved to be able to improve soil structure and enhance plant resistance to environmental stress (Audet and Charest, 2006; Abdel-Fattah and Asrar, 2011; Asrar and Elhindi, 2011; Abdel-Fattah et al., 2011). Recently, the enhanced degradation of organic pollutant in soils in the presence of AM was observed, indicating that arbuscular mycorrhizal bioremediation is a promising and prospective technique for soils contaminated with organic pollutant ( $\mathrm{Li}$ et al., 2006; Shen et al., 2006).

In Saudi Arabia, Kalanchoe biossfeldiana (family, Crassulaceae) is one of the most important flowering pot plants. With its variation in leaf shape, flower colors, and good keeping quality in the home. The kalanchoe is a succulent with fleshy leaves and has good potential as a flowering potted plant for many growers. The leaves are arranged along the stems in pairs, each pair at right angles to the pair above or below. The small, star-shaped florets are produced under short day conditions (Schwabe, 1969).

It has been demonstrated that plants colonized by the arbuscular mycorrhizal (AM) fungi are usually more tolerant to heavy metals in wastewater than plants without these symbionts (Gaur and Adholeya, 2004; Soares and Siqueira, 2008; Rashid et al., 2009), but mechanisms underlying this protections are largely unknown. It has been suggested that the AM effects on host plant tolerance to heavy metals may depend on reduced metal uptake because of retention and immobilization in chitin or glomalin in the fungal wall (Khan et al., 2000; Gonzalez-Chavez et al., 2004) and reduced metal transfer from roots to shoots (Bi et al., 2003; Christie et al., 2004). Other protective effects may include metal dilution in plant tissue as a result of increased root or shoot growth, uptake exclusion by precipitation or chelation in the rhizosphere (Kaldorf et al., 1999). In addition, AM fungi exude enzymes that participate in the immobilization process of soil contamination in which case accumulation in plant is reduced (Weissenhorn et al., 1993; Audet and Charest, 2006).

Little information is known about the beneficial role of AM fungi to overcome the toxicity of heavy metals in sewage water polluted soil. In this study, pot experiments were carried out to evaluate the effects of an AM fungus, Glomus deserticola (isolated from sewage water contaminated soil) inoculation on the growth, flower yield, heavy metal tolerance of Kalanchoe biossfeldiana plants grown in soil contaminated with different concentrations of sewage water provided from Durab Irrigation Experimental Station, Riyadh, Saudi Arabia. Furthermore, the effects of sewage water concentrations on the levels of mycorrhizal colonization of kalanchoe plants were also investigated. 


\section{MATERIALS AND METHODS}

\section{Mycorrhizal inoculum}

Glomus constrictum Trappe was isolated from the rhizosphere soil of Zea mays in Durab Experimental Station, where the soil had been contaminated by sewage water. The single spore of $G$. constrictum was multiplied with sudangrass (Sorghum halepense L.) plants for 4 months using autoclaved polluted sand soil collected from the same site, in controlled environmental greenhouse conditions ( $25^{\circ} \mathrm{C}$ day / $20{ }^{\circ} \mathrm{C}$ night temperature, $65 \%$ relative humidity, $16 / 18 \mathrm{hrs}$ light / dark period cycle with a photosynthetic photon flux density of $500-700 \mu \mathrm{mol} . \mathrm{m}^{-2} \mathrm{~s}^{-1}$ ) at College of Food and Agriculture Sciences, King Saud University. Plants were irrigated with tap water as needed and the nutrient solution (Long-Ashton without phosphorus) of plants was supplied. The inoculums consisted of rhizoshere soil, spores and mycelium of G. constrictum.

\section{Sewage water}

Four levels of polluted sewage water $(0 \%, 25 \%, 50 \%$ and $75 \%$ diluted with tap water) provided from Durab Irrigation Experimental Station, Riyadh, Saudi Arabia) were used in this experiment. The chemo-physical analysis of the polluted sewage water is listed in Table 1.

Table 1: Chemical analysis of pollutes sewage water used throughout this study.

\begin{tabular}{|l|c|}
\hline \multicolumn{1}{|c|}{ Constituents } & Concentration \\
\hline E.C $(\mathrm{ds} / \mathrm{m})$ & 1.11 \\
$\mathrm{pH}$ & 5.92 \\
Total hardness & $25.0 \mathrm{ppm}$ \\
Total suspended compounds & $123 \mathrm{ppm}$ \\
Zinc & $10.50 \mathrm{ppm}$ \\
Copper & $5.5 \mathrm{ppm}$ \\
Manganese & $30.2 \mathrm{ppm}$ \\
Cobalt & $1.2 \mathrm{ppm}$ \\
Phosphate & $47 \mathrm{ppm}$ \\
Nitrate & $14 \mathrm{ppm}$ \\
Organic matter & $8.4 \%$ \\
Total N & $0.34 \%$ \\
\hline
\end{tabular}

\section{The soil}

The soil used in this study was collected from the top layer $(5-20$ $\mathrm{cm}$ ) of Durab Experimental Station. Soils were thoroughly mixed, air dried and sieved through a $4-\mathrm{mm}$ sieve before sterilization (20 min at $120{ }^{\circ} \mathrm{C}$ ) to eliminate viable AM fungal propagules. Before packing into plastic pots (2.5 $\mathrm{kg} / \mathrm{pot}$ ), mixed soil samples were analyzed for the main physio-chemical properties. The soil type was sandy loam with the following properties: soil $\mathrm{pH}$ (soil / water ratio of $1: 2.5 \mathrm{w} / \mathrm{v}$ ) 7.8 , an organic matter of $1.2 \%$, a total $\mathrm{N}$ of $0.02 \%$, a total phosphorus 0.4 ppm, $22 \mu \mathrm{g} / \mathrm{g} \mathrm{Zn}, 137 \mu \mathrm{g} / \mathrm{g} \mathrm{Mn}$. 
Asrar, A. A.

\section{Growth conditions}

The factorial block design (one plant $\mathrm{sp}$. $X$ two arbuscular mycorrhizal treatments $X 4$ sewage water concentrations) used in this experiment consisted of $\mathrm{AM}$ and non-AM plants grown in soil subjected to four levels of sewage water. These eight treatments were replicated seven times to give a total of 56 pots. Half of the pots (AM) were inoculated with Glomus constrictum as a $3 \mathrm{~cm}$ thick layer of inoculum substrate containing 5 $\mathrm{g}$ of stock culture soil / pot (80 mycorrhizal spores / g soil), whereas an equivalent volume of control substrate (without propagules) was incorporated in the non-mycorrhizal pots (non-AM). Plants were distributed randomly and grown in a glasshouse of the Plant Production Department, College of Food and Agriculture Science, under natural day / night conditions (minimum / maximum temperature, relative humidity and day length, $25 / 17{ }^{\circ} \mathrm{C}, 55 / 65$ and 10/14 hrs; respectively). Four weeks after planting, each treatment was watered with an equal volume of the corresponding sewage water level $(0 \%$, $25 \%, 50 \%$ and $75 \%$ respectively). All the plants were fertilized weekly (100 $\mathrm{ml} /$ pot) from week 6 to 10 using a modified Long-Ashton nutrient solution minus phosphorus.

\section{Harvest}

All the plants were harvested 12 weeks after planting. Shoot heights were measured. The fresh plant tissues were weighted separately as shoots and roots biomass. Leaf area of the plants for each treatment was measured with a leaf area meter (Li-Cor, Lincoin, 404, NE). Shoots and roots were oven dried at $80 \stackrel{\circ}{\circ}$ for $24 \mathrm{~h}$ and weighted. Flower fresh and dry weights, number and diameter of inflorescences, flowers number and spike lengths of the plants were also recorded. The relative content of chlorophyll was measured using SPAD-502 portable chlorophyll apparatus. The dependence of plant on mycorrhiza (MD) was defined as the percentage of the plant growth that was subject to the adding of AM, and calculated with the following formula (Menge et al., 1978)

$\mathrm{MD}(\%)=100 \times$ fflower fresh weight of mycorrhizal plants - flower fresh weight of non-mycorrhizal plants\} / \{flower fresh weight of nonmycorrhizal plants\}

Part of roots for each treatment were washed gently with tap water, cleared $45 \mathrm{~min}$ in $7 \% \mathrm{KOH}$ at $90 \mathrm{C}$, rewashed with tap water, acidified in $1 \%$ $\mathrm{HCl}$ and stained in $0.05 \%$ trypan blue in lactophenol. Mycorrhizal colonization levels the frequency of colonization ( $F \%)$, the intensity of colonization ( $\mathrm{M} \%$ ) and rate of arbuscular development $(\mathrm{A} \%)\}$ of the stained roots were estimated by the method of Trouvelot et al. (1986).

Total phosphorus in the dry tissue of leaves was determined by the vanadono-molybdophosphoric colorimetric method (Jackson, 1958). Total nitrogen was determined by the Kjeldahl method (Nelson and Sommers, 1973). Potassium was assayed directly by atomic absorption spectrophotometer Shimadzu AA-670 (price, 1979). Oven-dried shoots and roots were milled and digested by $5 \mathrm{ml}$ concentrated $\mathrm{HNO} 3$ at $160 \stackrel{\circ}{\circ} \mathrm{C}$ using microwave accelerated reduction system (Mars 5, CEM Co. Ltd, USA). The dissolved samples were analyzed for $\mathrm{Zn}, \mathrm{Cu}$, Co and $\mathrm{Mn}$ concentrations and measured by inductively coupled plasma-optical emission spectroscopy using 
a Perkin Elmer Optima 2000 Dv (Pearson and Jakobsen, 1993). Tolerance indices (Ti) of mycorrhizal and non-mycorrhizal plants to polluted sewage water were determined according to Shetty et al. (1995) as follow:

$\mathrm{Ti}=100 \mathrm{X}$ \{shoot dry weight of plants at polluted level / shoot dry

\section{Statistical analysis} weight of plants at control level\}

Experiments were conducted with seven replicates per treatment. The data were subjected to statistical analysis using two - factor analysis of variance (ANOVA). Means were separated by Duncan's multiple range tests at the $5 \%$ level using Costat software (Cohort, Berkeley, Calif.).

\section{RESULTS}

\section{Plant growth}

Shoot and root biomass and shoot height of both mycorrhizal and non-mycorrhizal plants grown in soil contaminated with sewage water were significantly lower than those plants grown in control (unpolluted) soil (Table 2). However, the reduction in the plant growth parameters was markedly distinct in non-mycorrhizal than mycorrhizal Kalanchoe plants (Plate 1). Shoot and root biomass and shoot height of the inoculated (AM) plants were significantly higher than that of the non-inoculated (Non-AM) plants at the all levels of sewage water contaminated soils. AM plants had significantly higher tolerance index (Ti) than the non-AM plants, and the rate of $\mathrm{Ti}$ was significantly decreased with increasing the sewage water level.

Table 2. Effect arbuscular mycorrhizal (AM) colonization on growth responses of Kalanchoe plants grown in sewage water contaminated soil.

\begin{tabular}{|c|c|c|c|c|c|c|c|}
\hline \multicolumn{2}{|c|}{ Treatments } & \multicolumn{2}{|c|}{$\begin{array}{l}\text { Fresh matter } \\
\text { (g / plant) }\end{array}$} & \multicolumn{2}{|c|}{$\begin{array}{l}\text { Dry matter } \\
\text { (g / plant) }\end{array}$} & \multirow{2}{*}{$\begin{array}{c}\text { Shoot } \\
\text { height } \\
\text { (cm / } \\
\text { plant) }\end{array}$} & \multirow{2}{*}{$\begin{array}{c}\text { Tolerance } \\
\text { indices } \\
\text { (TI) }\end{array}$} \\
\hline $\begin{array}{c}\text { Sewage water } \\
\text { level (\%) }\end{array}$ & $\begin{array}{l}\text { AMF } \\
\text { status }\end{array}$ & Shoot & Root & Shoot & Root & & \\
\hline \multirow{2}{*}{$\begin{array}{l}0.0 \\
(\text { check) }\end{array}$} & Non-AM & $30.90 c^{*}$ & 2.08 & $1.75 \mathrm{c}$ & $0.35 \mathrm{c}$ & $18.1 \mathrm{bc}$ & - \\
\hline & AM & $51.16 \mathrm{~b}$ & $3.52 \mathrm{~b}$ & $2.35 \mathrm{~b}$ & $0.42 \mathrm{~b}$ & $20.4 \mathrm{~b}$ & - \\
\hline \multirow[b]{2}{*}{25} & Non-AM & $31.39 \mathrm{~cd}$ & $2.26 \mathrm{bc}$ & $1.80 \mathrm{c}$ & $0.39 \mathrm{bc}$ & $19.2 \mathrm{~b}$ & $1.02 \mathrm{~b}$ \\
\hline & AM & $86.55 \mathrm{a}$ & $4.34 \mathrm{a}$ & $4.15 \mathrm{a}$ & $0.60 \mathrm{a}$ & $23.9 \mathrm{a}$ & $1.77 \mathrm{a}$ \\
\hline \multirow{3}{*}{50} & Non-AM & $25.87 d$ & $2.10 \mathrm{bc}$ & $1.51 \mathrm{~cd}$ & $0.32 \mathrm{c}$ & $16.9 \mathrm{c}$ & $0.86 \mathrm{c}$ \\
\hline & AM & $44.85 \mathrm{bc}$ & $2.50 \mathrm{~b}$ & $2.45 \mathrm{~b}$ & $0.44 \mathrm{~b}$ & $20.4 b$ & $1.04 \mathrm{~b}$ \\
\hline & Non-AM & $16.87 \mathrm{e}$ & $1.31 \mathrm{~d}$ & $0.95 \mathrm{~d}$ & $0.21 \mathrm{~d}$ & $15.2 \mathrm{c}$ & $0.54 \mathrm{~d}$ \\
\hline \multirow{2}{*}{\begin{tabular}{|l}
75 \\
LSD (0.05) \\
\end{tabular}} & AM & $38.14 \mathrm{c}$ & $1.84 \mathrm{c}$ & $1.67 \mathrm{~cd}$ & $0.30 \mathrm{~cd}$ & $18.0 \mathrm{bc}$ & $0.71 \mathrm{c}$ \\
\hline & & 10.25 & 0.402 & 0.349 & 0.052 & 2.44 & 0.210 \\
\hline
\end{tabular}

*Values in each column followed by the same letter(s) are not significantly different at $\boldsymbol{P} \leq$ 0.05 (Duncan's multiple range test).

$\mathrm{TI}=$ shoot dry weight of plants at polluted level / shoot dry weight of plants at check level

Leaf area, relative chlorophyll and magnesium contents of mycorrhizal and non-mycorrhizal plants increased at the concentration of 25 $\%$ sewage water, and then reduced as sewage water concentration increased (Table 3). The relative chlorophyll content, leaf area and $\mathrm{Mg}$ content of the mycorrhizal plants was significantly higher than that of the non- 
Asrar, A. A.

inoculated plants grown in soil contaminated with different levels of sewage water stress, indicating that high concentration of sewage water stress might inhibit leaf area and $\mathrm{Mg}$ content of Kalanchoe plants.

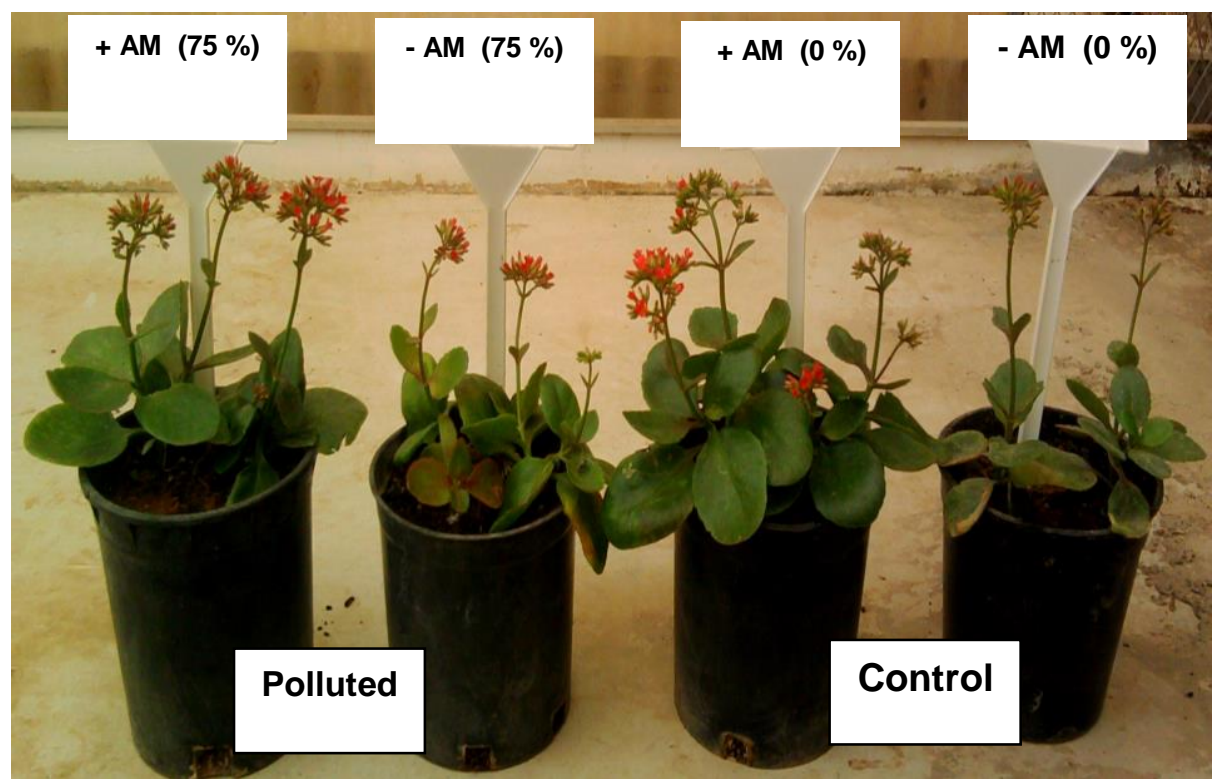

Plate (1). Growth of mycorrhizal (+AM) and non-mycorrhizal (-AM) Kalanchoe plants in soil irrigated either with sewage polluted water $(75 \%)$ or tap water $(0 \%$, control).

Table 3. Effect arbuscular mycorrhizal (AM) colonization on the content of chlorophyll, leaf area and leaf magnesium content of Kalanchoe plants grown in sewage water contaminated soil.

\begin{tabular}{|c|c|c|c|c|}
\hline $\begin{array}{c}\text { Sewage water } \\
\text { level }(\%)\end{array}$ & AMF status & $\begin{array}{l}\text { Relative content } \\
\text { of chlorophyll }\end{array}$ & $\begin{array}{l}\text { Leaf area } \\
\text { (cm²/plant) }\end{array}$ & $\begin{array}{c}M g \\
\text { (mg g } g^{-1} \text { dwt) }\end{array}$ \\
\hline 0.0 & Non-AM & $20.26 c^{*}$ & $128.7 \mathrm{~cd}$ & $1.63 \mathrm{c}$ \\
\hline (check) & AM & $25.32 \mathrm{~b}$ & $196.6 \mathrm{~b}$ & $1.96 \mathrm{~b}$ \\
\hline & Non-AM & $21.67 c$ & $135.1 \mathrm{c}$ & $1.73 \mathrm{c}$ \\
\hline 25 & AM & $27.50 \mathrm{a}$ & $280.4 \mathrm{a}$ & $2.23 \mathrm{a}$ \\
\hline & Non-AM & $17.76 \mathrm{~d}$ & 116.3 & $1.58 \mathrm{e}$ \\
\hline 50 & $\mathrm{AM}$ & $19.12 \mathrm{~cd}$ & $180.9 \mathrm{~b}$ & $1.88 \mathrm{c}$ \\
\hline & Non-AM & $11.55 \mathrm{e}$ & $77.8 \mathrm{~d}$ & $1.26 \mathrm{~d}$ \\
\hline 75 & AM & $16.10 \mathrm{~d}$ & $143.2 \mathrm{c}$ & $1.59 \mathrm{e}$ \\
\hline LSD (0.05) & & 2.095 & 20.75 & 0.246 \\
\hline
\end{tabular}
0.05 (Duncan's multiple range test).

\section{Flower yield}

Flower fresh and dry weights, spike length, inflorescences diameter and flowers numbers of sewage water stressed mycorrhizal and mycorrhizal Kalanchoe plants were significantly lower than those for unpollted plants (Table 4) particularly at $50 \%$ and $75 \%$ concentrations of sewage water. 
However, the reduction rate in flower parameters due to sewage water stress was more pronounced in non-mycorrhizal than in mycorrhizal plants. On other hand, AM plants had higher flowers fresh and dry weights, inflorescences diameter and spike length than non-AM plants regardless of sewage water treatments. Mycorrhizal dependency values (flower frsh weight) for Kalanchoe plants in response to AM inoculation were significantly higher under sewage stressed than unpolluted conditions (Table 4) and these values were increased as sewage water stress level increased,

Table 4. Effect arbuscular mycorrhizal (AM) colonization on flower yield of Kalanchoe plants grown in sewage water contaminated soil.

\begin{tabular}{|c|c|c|c|c|c|c|c|}
\hline \multicolumn{2}{|c|}{ Treatments } & \multicolumn{5}{|c|}{ Flower yield per plant } & \multirow[b]{2}{*}{$\begin{array}{l}\text { Dependence } \\
\text { on AMF (\%) }\end{array}$} \\
\hline $\begin{array}{c}\text { Sewage } \\
\text { water level } \\
(\%)\end{array}$ & AMF status & $\begin{array}{c}\text { Spike } \\
\text { length } \\
\text { (cm) }\end{array}$ & $\begin{array}{l}\text { Flowers } \\
\text { number }\end{array}$ & $\begin{array}{c}\text { ID } \\
\left(\mathrm{cm}^{2}\right)\end{array}$ & $\begin{array}{l}\text { Flower } \\
\text { fwt. (g) }\end{array}$ & $\begin{array}{l}\text { Flower } \\
\text { dwt. (g) }\end{array}$ & \\
\hline \multirow{2}{*}{$\begin{array}{l}0.0 \\
(\text { check) }\end{array}$} & Non-AM & $2.8 \mathrm{~d}^{*}$ & $27 \mathrm{e}$ & $5.5 \mathrm{~d}$ & $4.83 \mathrm{de}$ & $0.21 \mathrm{de}$ & - \\
\hline & AM & $5.3 \mathrm{~b}$ & $53 \mathrm{c}$ & $9.0 \mathrm{~b}$ & $7.34 \mathrm{c}$ & $0.68 \mathrm{c}$ & $52 \mathrm{~d}$ \\
\hline \multirow[b]{2}{*}{25} & Non-AM & $4.1 \mathrm{c}$ & $80 \mathrm{~b}$ & $7.6 \mathrm{c}$ & $7.40 \mathrm{c}$ & $0.67 \mathrm{c}$ & - \\
\hline & AM & $6.2 \mathrm{a}$ & $135 \mathrm{a}$ & $13 \mathrm{a}$ & $12.34 \mathrm{a}$ & $1.22 \mathrm{a}$ & $66 \mathrm{c}$ \\
\hline \multirow{3}{*}{50} & Non-AM & $3.6 \mathrm{~cd}$ & $25 \mathrm{e}$ & $7.0 \mathrm{c}$ & $5.07 \mathrm{~d}$ & $0.34 \mathrm{~d}$ & - \\
\hline & AM & $4.7 \mathrm{c}$ & $85 \mathrm{~b}$ & $10.5 \mathrm{~b}$ & $10.23 \mathrm{~b}$ & $0.86 \mathrm{~b}$ & $95 \mathrm{~b}$ \\
\hline & Non-AM & $1.9 \mathrm{e}$ & $21 \mathrm{e}$ & $3.3 \mathrm{e}$ & $2.91 \mathrm{e}$ & $0.11 \mathrm{e}$ & - \\
\hline \multirow{2}{*}{\multicolumn{2}{|c|}{ LSD (0.05) }} & $2.3 \mathrm{~d}$ & $37 \mathrm{~d}$ & $5.8 \mathrm{~d}$ & $6.34 \mathrm{~cd}$ & $0.39 \mathrm{~d}$ & $118 \mathrm{a}$ \\
\hline & & 1.065 & 8.22 & 1.202 & 2.10 & 0.201 & 12.5 \\
\hline
\end{tabular}

*Values in each column followed by the same letter(s) are not significantly different at $\boldsymbol{P} \leq$ 0.05 (Duncan's multiple range test). Where, ID; Inflorescence diameter

Dependence of AMF = $100 \times$ fflower fresh weight of AM plants - flower fresh weight of non-AM plants / flower fresh weight of non-AM plants

\section{Mycorrhizal colonization levels}

With the increase of the sewage water concentration in the soil, the frequency $(\%)$, intensity (M\%) of mycorrhizal colonization and arbuscular development $(\mathrm{A} \%)$ on Kalanchoe roots were gradually declined (Table 5 ), and this effect was markedly distinct with the highest sewage water levels. However, no significant differences were observed in the levels of mycorrhizal colonization between AM plants grown in unpolluted (control) and $25 \%$ sewage water contaminated soils. No signs of mycorrhizal colonization were observed in the non-inoculated plants.

\section{Nutrients content}

The data in Table (6) show that AM Kalanchoe plants had higher shoot and root $\mathrm{P}, \mathrm{N}$ and $\mathrm{K}$ contents than non-AM plants, regardless of sewage water treatments. However, both mycorrhizal and non-mycorrhizal plants grown in control (unpolluted) soil had higher $\mathrm{P}, \mathrm{N}$ and $\mathrm{K}$ contents than sewage water stresses plants particularly at higher concentrations $(50 \%$ and $75 \%$ ). Reduction in shoot and root nutrient contents as a result of sewage water stress was more pronounced in non-mycorrhizal than in mycorrhizal Kalanchoe plants. 
Asrar, A. A.

Table 5. Frequency ( $F \%$ ), Intensity of mycorrhizal colonization ( $M$ \%) and arbuscular frequency (A \%) in the root tissues of mycorrhizal (AM) and non-mycorrhizal (Non-AM) Kalanchoe plants grown in sewage water contaminated soil.

\begin{tabular}{|c|c|c|c|c|}
\hline \multicolumn{2}{|c|}{ Treatments } & \multicolumn{3}{|c|}{$\begin{array}{l}\text { Levels of mycorrhizal colonization } \\
\qquad(\%)\end{array}$} \\
\hline Sewage water level (\%) & AMF status & $\mathbf{F}$ & $\mathbf{M}$ & $\mathbf{A}$ \\
\hline \multirow{2}{*}{$\begin{array}{l}0.0 \\
\text { (check) }\end{array}$} & Non-AM & $0.0 \mathrm{~d}$ & $0.0 \mathrm{e}$ & $0.0 \mathrm{~d}$ \\
\hline & AM & $90 \mathrm{a}$ & $75.5 \mathrm{a}$ & $60.7 \mathrm{a}$ \\
\hline \multirow[b]{2}{*}{25} & Non-AM & $0.0 \mathrm{~d}$ & $0.0 \mathrm{e}$ & $0.0 \mathrm{~d}$ \\
\hline & AM & $89 \mathrm{a}$ & $77.5 \mathrm{a}$ & $61.0 \mathrm{a}$ \\
\hline \multirow[b]{2}{*}{50} & Non-AM & $0.0 \mathrm{~d}$ & $0.0 \mathrm{e}$ & $0.0 \mathrm{~d}$ \\
\hline & AM & $84 \mathrm{~b}$ & $62.5 \mathrm{~b}$ & $52.6 \mathrm{~b}$ \\
\hline \multirow[b]{2}{*}{75} & Non-AM & $0.0 \mathrm{~d}$ & $0.0 \mathrm{e}$ & $0.0 \mathrm{~d}$ \\
\hline & AM & $73 \mathrm{c}$ & $45.0 \mathrm{c}$ & $38.4 \mathrm{c}$ \\
\hline LSD (0.05) & & 10.11 & 8.56 & 5.01 \\
\hline
\end{tabular}

${ }^{\star}$ Values in each column followed by the same letter(s) are not significantly different at $\boldsymbol{P} \leq$ 0.05 (Duncan's multiple range test).

Table 6. Effect arbuscular mycorrhizal (AM) colonization on mineral nutrient contents ( $\mathrm{mg} \mathrm{g}^{-1} \mathrm{dwt}$.) in both shoots and roots of Kalanchoe plants grown in sewage water contaminated soil.

\begin{tabular}{|c|c|c|c|c|c|c|c|}
\hline \multirow{2}{*}{$\begin{array}{c}\text { Sewage water } \\
\text { level (\%) }\end{array}$} & \multirow{2}{*}{$\begin{array}{l}\text { AMF } \\
\text { status }\end{array}$} & \multicolumn{3}{|c|}{ Shoot } & \multicolumn{3}{|c|}{ Root } \\
\hline & & $\mathbf{N}$ & $\mathbf{P}$ & $\mathrm{K}$ & $\mathbf{N}$ & $\mathbf{P}$ & $\mathrm{K}$ \\
\hline 0.0 & Non-AM & $30.50 a^{*}$ & $2.47 \mathrm{~b}$ & $15.01 \mathrm{c}$ & $19.90 \mathrm{~b}$ & $1.97 \mathrm{~d}$ & $12.10 \mathrm{c}$ \\
\hline (check) & AM & $34.69 \mathrm{a}$ & $3.07 \mathrm{a}$ & $21.21 \mathrm{~b}$ & $22.47 \mathrm{a}$ & $2.60 \mathrm{~b}$ & $16.52 \mathrm{~b}$ \\
\hline & Non-AM & $31.20 \mathrm{~b}$ & $2.61 \mathrm{~b}$ & $18.00 \mathrm{bc}$ & $19.40 \mathrm{~b}$ & $2.36 \mathrm{c}$ & $13.00 \mathrm{c}$ \\
\hline 25 & AM & $36.11 \mathrm{a}$ & $3.30 \mathrm{a}$ & $24.11 \mathrm{a}$ & $22.80 \mathrm{a}$ & $3.02 \mathrm{a}$ & $18.20 \mathrm{a}$ \\
\hline & Non-AM & $22.06 \mathrm{~d}$ & $1.40 \mathrm{~d}$ & $16.94 \mathrm{c}$ & $16.07 \mathrm{~cd}$ & $1.21 \mathrm{f}$ & $11.90 \mathrm{~d}$ \\
\hline 50 & AM & $26.07 \mathrm{c}$ & $1.94 \mathrm{c}$ & $20.10 \mathrm{~b}$ & $18.08 \mathrm{c}$ & $1.71 \mathrm{e}$ & $15.11 \mathrm{~b}$ \\
\hline & Non-AM & $17.03 \mathrm{e}$ & $1.13 \mathrm{e}$ & $13.50 \mathrm{~d}$ & $13.11 \mathrm{~d}$ & $1.02 \mathrm{~g}$ & $09.98 \mathrm{e}$ \\
\hline 75 & AM & $22.84 \mathrm{~d}$ & $1.46 \mathrm{~d}$ & $16.80 \mathrm{c}$ & $16.28 \mathrm{~cd}$ & $1.35 \mathrm{f}$ & $13.22 \mathrm{c}$ \\
\hline LSD (0.05) & & 3.11 & 0.255 & 2.81 & 2.08 & 0.195 & 1.78 \\
\hline
\end{tabular}

*Values in each column followed by the same letter(s) are not significantly different at $P \leq$ 0.05 (Duncan's multiple range test).

\section{Metals content}

Shoots and roots $\mathrm{Zn}, \mathrm{Cu}, \mathrm{Co}$ and $\mathrm{Mn}$ contents of mycorrhizal and non-mycorrhizal maize plants were increased by increasing sewage water in the soil (Table 7). Mycorrhizal colonization significantly reduced shoot and root metals content when compared to non-mycorrhizal Kalanchoe plants grown in soil contaminated with different concentrations of sewage water. On the other hand, AM Kalanchoe plants exhibited high shoots and roots $\mathrm{Zn}, \mathrm{Cu}$, Co and $\mathrm{Mn}$ contents when compared with non-AM plants grown in unpolluted (control) soils. Comparing root to shoot in mycorrhizal plants, the results recorded in Table (7) show that these are two fold (approximately) higher in the roots than in the shoots for metal contents. 
Table 7. Effect arbuscular mycorrhizal (AM) colonization on heavy metals concentrations $\left(\mu^{-1} \mathrm{dwt}\right.$.) in both shoots and roots of Kalanchoe plants grown in sewage water contaminated soil.

\begin{tabular}{|c|c|c|c|c|c|c|c|c|c|}
\hline \multirow{2}{*}{$\begin{array}{l}\text { Sewage } \\
\text { water } \\
\text { level }(\%)\end{array}$} & \multirow{2}{*}{$\begin{array}{l}\text { AMF } \\
\text { status }\end{array}$} & \multicolumn{4}{|c|}{ Shoot } & \multicolumn{4}{|c|}{ Root } \\
\hline & & $\mathrm{Zn}$ & $\mathrm{Cu}$ & Co & Mn & $\mathrm{Zn}$ & $\mathrm{Cu}$ & Co & Mn \\
\hline \multirow{2}{*}{$\begin{array}{l}0.0 \\
\text { (check) }\end{array}$} & Non-AM & $105 f^{*}$ & $31.6 \mathrm{e}$ & $16.3 \mathrm{c}$ & $61 \mathrm{e}$ & $120 \mathrm{~g}$ & $140 \mathrm{f}$ & $18.1 \mathrm{e}$ & $40 \mathrm{f}$ \\
\hline & AM & 120 ef & $18.1 \mathrm{de}$ & $18.1 \mathrm{de}$ & $67 \mathrm{e}$ & $210 \mathrm{f}$ & $150 \mathrm{e}$ & $19.3 \mathrm{e}$ & $45 \mathrm{f}$ \\
\hline \multirow[b]{2}{*}{25} & Non-AM & $170 \mathrm{~d}$ & $25.6 \mathrm{c}$ & $25.6 \mathrm{c}$ & $110 \mathrm{de}$ & $180 \mathrm{de}$ & $180 \mathrm{c}$ & $32.1 \mathrm{~d}$ & $69 \mathrm{~d}$ \\
\hline & AM & $132 \mathrm{e}$ & $20.0 \mathrm{~d}$ & $20.0 \mathrm{~d}$ & $95 \mathrm{~d}$ & $150 \mathrm{e}$ & $165 \mathrm{~d}$ & $30.3 \mathrm{~d}$ & $60 \mathrm{e}$ \\
\hline \multirow[b]{2}{*}{50} & Non-AM & $230 \mathrm{c}$ & $33.1 \mathrm{~b}$ & $30.0 \mathrm{~b}$ & $150 \mathrm{c}$ & $313 c$ & $215 b$ & $45.4 \mathrm{~b}$ & $130 \mathrm{~b}$ \\
\hline & AM & $185 \mathrm{e}$ & $25.8 \mathrm{c}$ & $25.8 \mathrm{c}$ & $100 \mathrm{~d}$ & $207 d$ & $188 \mathrm{c}$ & $38.3 \mathrm{c}$ & $95 \mathrm{c}$ \\
\hline \multirow{3}{*}{\begin{tabular}{|l}
75 \\
$\operatorname{LSD}(0.0$
\end{tabular}} & Non-AM & $341 \mathrm{a}$ & $45.0 \mathrm{a}$ & $45.0 \mathrm{a}$ & $180 \mathrm{a}$ & $510 \mathrm{a}$ & $295 \mathrm{a}$ & $56.8 \mathrm{a}$ & $155 \mathrm{a}$ \\
\hline & AM & $280 \mathrm{~b}$ & $32.3 \mathrm{~b}$ & $32.3 \mathrm{~b}$ & $120 \mathrm{~b}$ & $385 \mathrm{~b}$ & $218 b$ & $40.1 \mathrm{~b}$ & $132 b$ \\
\hline & & 25.1 & 5.82 & 5.82 & 10.3 & 30.9 & 13.23 & 7.11 & 10.6 \\
\hline
\end{tabular}

*Values in each column followed by the same letter(s) are not significantly different at $P \leq$ 0.05 (Duncan's multiple range test).

It appears from the present study that arbuscular mycorrhizal (AM) inoculation improved growth and flower yield of Kalanchoe plants grown in either unpolluted or sewage water contaminated soils compared to nonmycorrhizal (non-AM) plants. The rate of growth in response to mycorrhizal colonization was more pronounced at higher levels of sewage water in soil. These results are in agreement with those reported by Shen et al. (2006) who reported that mycorrhizal inoculation increased growth of maize plants with enchancement of $\mathrm{P}$ nutrition, perhaps increasing plant tolerance to $\mathrm{Cd}$ and $\mathrm{Zn}$ or by lowering the concentrations of soluble heavy metals in the soil dilution and / or by adsorption onto the extrametrical mycelium of mycorrhizal fungi. Enhanced growth and flower yield of mycorrhizal plants are often related to improve P acquisition (Wang et al., 2005; Soares and Siqueira, 2008) who suggested that AM protecting effect against heavy metal toxicity could be mediated by the enhancement of $P$ nutrition. This study showed that AM fungi could form mycorrhizal symbionts in Kalanchoe plants, indicating that mycorrhizal rehabilitation of sewage water contaminated soil was a feasible solution.

The relative chlorophyll content of Kalanchoe plants was reduced under sewage water stress. The polluted sewage water might affect the synthesis of chlorophyll enzyme, thereby reducing the plants photosynthesis and inhibiting the growth of plants (Feng, 2006). The study found that the inoculation of AMF could improve the chlorophyll synthesis in plants and increase the photosynthesis of plant (Wang et al., 2005). Moreover, the results indicated that arbuscular mycorrhizae might increase the chlorophyll content, improve the synthesis capacity of maize plants (Rashid et al., 2009) and protect or slow the process of chlorophyll degradation (Tang et al., 2009).

The present study demonstrated that the levels of mycorrhizal colonization in Kalanchoe root decreased with increasing sewage water concentrations in the soil. The results obtained here are in agreement with the study of Tang et al. (2009) who demonstrated that the colonization rate of AMF on maize root decreased with the increase of diesel concentration in the soil. In other study, Gong et al. (2002) reported that the organic matter contamination 
did not affect the colonization of AM fungi on poplar. However, other studies have reported high levels of mycorrhizal colonization in agricultural soils contaminated with metals of different origins (Audet and Charest, 2006; Wang et al., 2008). The inconsistence of the results may be probably due to the origin of mycorrhizal fungus, plant species and the dose of heavy metal used (Bradely et al., 1982; Khan et al., 2000; Soares and Siqueira, 2008).

Of particular interest in this study, the concentrations of zinc, cobalt, cupper and manganese in shoots and roots of mycorrhizal Kalanchoe plants were significantly lower than that in non-mycorrhizal plants grown at higher levels of sewage water contaminated soils. These results corroborate those by Soares and Siqueira (2008) who reported that mycorrhizal colonization reduced the shoot concentrations of $\mathrm{Cd}$ and $\mathrm{Zn}$ in field growing maize and grass when the soil had high available concentrations of both metals. A possible reason for such reduction may be that $A M$ plants yielded higher biomass, which contributed to dilute metals in the shoot tissue (Cavagnaro, 2008; Soares and Siqueira, 2008) or that the AM mycelium retained the absorbed metals (Chen et al., 2007; Repetto et al., 2007). Metal immobilization in fungal tissues can occur as metal sequestration in fungal wall components such as the glycoproteins-glomalins, which have high affinity to metals (Gonzalez-Chavez et al., 2004). Accordingly, the mycorrhizal fungi may have immobilized soil contaminants and prevented these from being taken up by the host plant, especially under increasingly toxic soil- $\mathrm{Zn}$ concentrations (Weissenhorn et al., 1995).

Under soil contamination, arbuscular mycorrhizal (AM) inoculation decreased all metals ( $\mathrm{Zn}, \mathrm{Co}, \mathrm{Cu}$ and $\mathrm{Mn}$ ) content in shoots and roots when compared to non-mycorrhizal Kalanchoe plants. These metal contents in the root tissues were much higher than in the shoot tissues. These results corroborate those by lee and George (2005) who suggested that AM inoculation can restrict root metal translocation to shoots by the formation of less mobile metal-phosphate compounds, thus favoring plant growth. In addition, an AM fungus enhances metal transference from sewage water contaminated soil to root. This contributes to the clearing up ability of this plant by removing greater amount of soil metals (Rashid et al., 2009). Additionally, accumulated metals were retained in the roots, therefore protecting the plant (Soares and Siqueira, 2008; Tang et al., 2009).The outcome of mycorrhizal colonization on clean-up of contaminated soils depends on the plant-fungusheavy metal combination and is also influenced by soil conditions (Gohre and Paszkowski, 2006; Wang et al., 2007).

\section{CONCLUSION}

The results obtained here concluded that AM inoculation has protection effects on Kalanchoe plants grown in sewage water contaminated soil. In fact that mycorrhizal plant absorbed less metal than non-mycorrhizal plants from the polluted soil. In this connection, mycorrhizal fungi exhibit reduced metal translocation and enhanced shoot growth, maintaining metal concentration at tolerable levels below toxicity-critical content. Probably, AM may play a 
significant role in soil remediation by enhancing metal removal from contaminated soil and protecting the host plant against metal toxicity.

Acknowledgements Author wishes to thank College of Food and Agricultural Research Centre and Deanship of Scientific Research, King Saud University, Saudi Arabia for supporting this research. We thank also Prof. Dr. AbdelFattah, G. (Plant Production Dep., College of Food and Agriculture Sciences, King Saud University) for isolation and identification of mycorrhizal fungus used in this study.

\section{REFERENCES}

Abdel-Fattah, G.M. and Rabie, G.H. (1985). The use of vesicular arbuscular mycorrhizal fungus (Glomus fasiculatum) to overcome the negative effects of the industrial effluents on the growth of cowpea. Pharmacy J., Zagazig Univ, 13: 34-40.

Abdel-Fattah, G.M. and Asrar, A.A. (2011). Arbusculr mycorrhizal fungal application to improve growth and tolerance of wheat (Triticum aestivum L.) plants grown in saline soil. Acta Physiol Plant (DOI 10.1997/s11738-011-0825-6).

Abdel-Fattah, G.M.; El-haddad, S.A.; Hafez, E.E. and Rashad, Y.M. (2911). Induction of defense responses in common bean plants by arbuscular mycorrhizal fungi. Microbiolgical Research, 166: 268-281.

Abdel-Fattah, G.M.; El-Dohlob, S.M.; El-Haddad, S.M.; Hafez, E.E. and Rashad, Y.M. (2009). An ecological view of arbuscular mycorrhizal status in some Egyptian plants. J. Environmental Sciences, 37: 123136.

Asrar, A.A. and Elhindi, K.M. (2011). Alleviation of drought stress of marigold (Tagetes erecta) plants by using arbuscular mycorrhizal fungi. Saudi Journal of Biological Sciences, 19: 38-46.

Ahmed, F.R.; Killham, K. and Alexander, I. (2006). Influences of arbuscular mycorrhizal fungus Glomus mosseae on growth and nutrition of lentil irrigated with arsenic contaminated water. Plant and Soil, 258: 33-41.

Audet, P.and Charest, C. (2006). Effects of AM colonization on "wild tobacoo" plants grown in zinc-contaminated soil. Mycorrhiza, 16: 227283.

Bi, Y.L.; Li, X.L. and Christie, P. (2003). Influence of early stages of arbuscular mycorrhiza on uptake of zinc and phosphorus by red clover from a low-phosphorus amended with zinc and phosphorus. Chemosphere, 50: 831-837.

Bradely, R., Burt, A. and Read, D.J. (1982). The biology of mycorrhiza in the Ericaceae. VII. The role of infection in heavy metal resistance. New Phytol., 99: 101-106.

Cavagnaro, T. R. (2008). The role of arbuscular mycorrhizas in improving plant zinc nutrition under low soil zinc concentrations: a review. Plant Soil, 304: 315-325. 
Chen, B. D.; Zhu, Y. G.; Duan, J.; Xiao, X. Y. and Smith, S. E. (2007). Effects of the arbuscular mycorrhizal fungus Glomus mosseae on growth and metal uptake by four plant species in copper mine tailings. Environmental Pollution, 147: 374-380.

Christie, P.; Li, X.L. and Chen, B.D. (2004). Arbuscular mycorrhiza can depress translocation of zinc to shoots of host plants in soils moderately polluted with zinc. Plant Soil, 261: 209-217.

Feng, G. (2006). Effects of single pollution of the different density mercury, lead and chromium on physiological and biochemical indexes of mungbean. Journal of Shanxi Agricultural University, 3: 382-387.

Gang, C.N.; Li, P.J.; Chen, S.H.; Xiao, B.Y.;Han, J.Y. and Zhang, C.G. (2002). Effects of different arbuscular mycorrhizal fungi on soil tolerance of Trifolium subterraneum L. Chinese Journal of Applied and Environmental Biology, 8: 648-652.

Gaur, A. and Adholeya, A. (2004). Prospects of arbusular mycorrhizal fungi in phytoremediation of heavy metal contaminated soils. Curr Sci India, 86:|538-534.

Gohre, V. and Paszkowski, U. (2006). Contribution of the arbuscular mycorrhizal symbiosis to heavy metal phytoremediation. Planta, 223: 1115-1122.

Gonzalez-Chavez, M. C.; Carrillo-Gonzalez, R.; Wright, S. F. and Nichols, K. A. (2004). The role of glomalin a protein produced by arbuscular mycorrhizal fungi, in sequestering potentially toxic elements, Environ. Pollut., 130: 317-323.

Heggo, A.M., Angle, J.S. and Chaney, R.L. (1990). Effects of vesiculararbuscular mycorrhizal fungi on heavy metal uptake by soybeans. Soil Biol. Biochem., 22: 865-869.

Huang, Y.; Jang, X.Y. and Tao, S. (2002). Contribution of mycorrhizal fungi to biodegradation of POPs in soil. Soil and Environmental Sciences, 11: 221-228.

Kaldorf, M.; Kuhn, A. J.; Schroder, W. R.; Hildebrandt, U. and Bothe, H. (1998). Selective element deposits in maize colonized by a heavy metal tolerance conferring arbuscular mycorrhizal fungus. J. Plant Physiol, 154: 718-728.

Khan, A. G.; Kuek, C.; Chaudhry, T. M.; Khoo, C. S. and Hayes, W. J. (2000). Role of plants, mycorrhizae and phytochelators in heavy metal contaminated land remediation. Chemosphere, 41: 197-207.

Lee, Y.J. and George, E. (2005). Contribution of mycorrhizal hyphae to the uptake of metal cations by cucumber plants at two levels of phosphorus supply. Plant Soil, 278: 361-370.

Menge, J.A.; Johnson, E.L.V. and Platt, R.G. (1978). Mycorrhizal dependency of several citrus cultivars under three nutrient regimes. New Phytologist, 81: 553-559.

Nelson, D.W. and Sommers, L.E. (1973). Determination of total nitrogen in plant material. Agronomy Journal, 65: 109-112.

Pearson, J.N. and Jakobsen, I. (1993). The relative contribution of hyphae and roots to phosphorus uptake by arbuscular mycorrhizal plants measured by dual labeling with ${ }^{32} \mathrm{P}$ and ${ }^{33} \mathrm{P}$. New Phytologist, 124: 489-494. 
Price, N.J. (1979). Spectrochemical analysis by atomic absorption : Pye Unicam Limited.

Rashid, A.; Ayub, N.; Ahmed, T.; Gul, J. and Khan, A.G. (2009). Phytoaccumulation prospects of cadmium and zinc by mycorrhizal plant species grown in industrially polluted soils. Environ Geochem Health, 31: 91-98.

Repetto, O.; Massa, N.; Gianinazzi-Pearson, V.; Dumas-Gaudot, E. and Berta, G. (2007). Cadmium effects on populations of root nuclei in two pea genotypes inoculated or not with the arbuscular mycorrhizal fungus Glomus mosseae. Mycorrhiza, 17: 111-120.

Schutzendubel, A. and Polle, A. (2002). Plant responses to abiotic stresses heavy metal-induced oxidative stress and production by mycorrhization. J Exp Bot., 53: 1351-1365.

Schwabe, E. (1969). Kalanchoes, in : the ball red book (Ball, V. ed.) pp. 372373. West Chicage, Lllinois.

Shaw, A.J. (1989). Heavy metal tolerance in plants: evolutionary aspects. CRC, New York, p 355.

Shetty, K.G.; Hetrick, B.A.D. and Schwab, A.P. (1995). Effects of mycorrhizae and fertilizer amendments on zinc tolerance of plants. Environmental Pollution, 88: 307-314.

Shen, H.; Christie, P. and L. X. (2006). Uptake of zinc, cadmium and phosphorus by arbuscular mycorrhizal maize (Zea mays L.) from a low available phosphorus calcareous soil spiked with zinc and cadmium. Environmental Geochmistry and Health, 28: 111-119.

Smith, F.A. and Smith, S.E. (1979). Structural diversity in vesiculararbuscular mycorrhizal symbioses. New phytol., 137: 373-388.

Soares, C. R. F. S. and Siqueira, J. Q. (2008). Mycorrhiza and phosphate protection of tropical grass species against heavy metal toxicity in multi-contaminated soil. Biol. Fertil. Soils, 44: 833-841.

Tang, M.; Chen, H.; Huang, J.C. and Tian, Z.Q. (2009). AM fungi effects on the growth and physiology of Zea mays seedlings under diesel stress. Soil Biology and Biochemistry, 41: 936-940.

Tordoff, G.M.; Baker, A.J.M. and Willis, A.J. (2000). Current approaches to the revegetation and reclamation of mettaliferous mine wasts. Chemosphere, 41: 219-228.

Trouvelot, A.; Kough, J.L. ang Gianinazzi-Pearson, V. (1986). Mesure du taux de mycorrhization d'un system radiculaire recherché de methods d'estimation ayant une signification fonctionnelle.. In: GininazziPearson, V. and Giainazzi, S. (eds). Physiological and genetical aspects of mycorrhiza. INRA Publications, Paris, pp. 217-221.

Vangronsveld, J. and Cunningham, S.D. (1998). Introduction to the concepts. In: Vangronsveld, J. and Cunningham, S.D (eds). Metal-contaminated soils; in situ inactivation and phyto-restoration. Springer, Dordrecht, pp $1-15$.

Wang, F.Y.; Lin, X.G. and Yin, R. (2005|). Heavy metal uptake by arbusular mycorrhizas of Elsholtzia splendens and the potential for phytoremediation of contaminated soil. Plant Soil, 269: 225-232.

Wang, F.Y.; Lin, X.G. and Yin, R. (2007). Role of microbial inoculation and chitosan in phytoextraction of $\mathrm{Cu}, \mathrm{Zn}, \mathrm{Pb}$ and $\mathrm{Cd}$ by Elsholtzia splendens - A field case. Environmental Pollution, 147: 248-255. 
Asrar, A. A.

Wang, Z-H.; Zhang, J-L.; Christie, P. and Li, X-L. (2008). Influence of inoculation with Glomus mosseae or Acaulospora morrowiae on arsenic uptake and translocation by maize. Plant Soil, 311: 235-244.

Weissenhorn, I.; Glashoff, A.; Leyval, C. and Berthelin, J. (1993). Differential tolerance to $\mathrm{Cd}$ and $\mathrm{Zn}$ of arbuscular mycorrhizal (AM) fungal spores isolated from heavy metal polluted and unpolluted soils. Plant Soil, 167: 189-196.

Weissenhorn, I.; Mench, M. and Leyval, C. (1995). Biovailability of heavy metals and arbuscular mycorrhizas in a sewage sludge amended sandy soil. Soil Biol. Biochem., 27: 287-296.

$$
\begin{aligned}
& \text { دور فطريات الجذور التكافلية الشجيرية في حماية نباتات الكلانشو ضد سمية }
\end{aligned}
$$

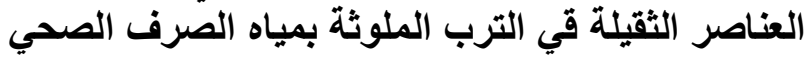

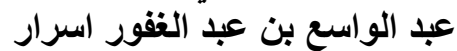

$$
\begin{aligned}
& \text { قسم الإنتاج النباتي_ كلية علوم الأغذية والزراعة ـ جامعة الملك سعود ـ ـ الملكة العربية }
\end{aligned}
$$

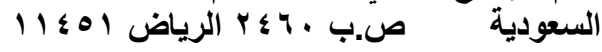

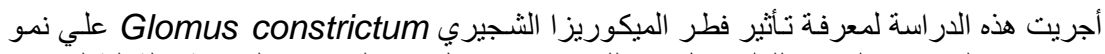

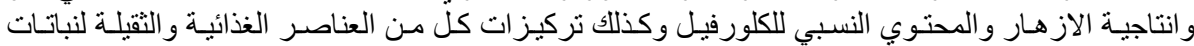

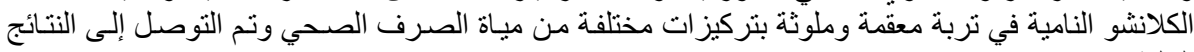

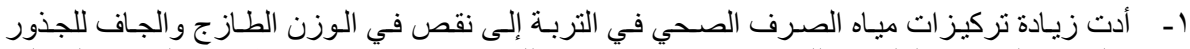

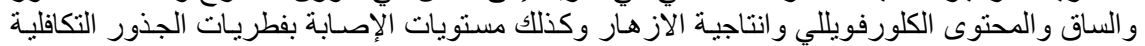

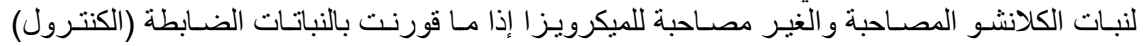

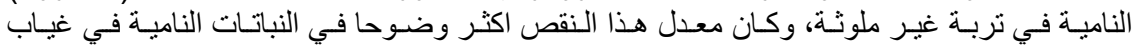

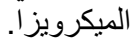

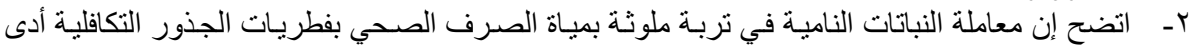

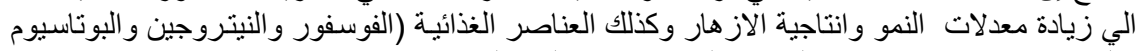

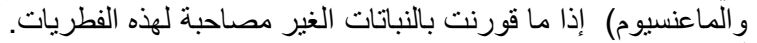

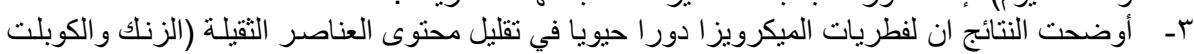

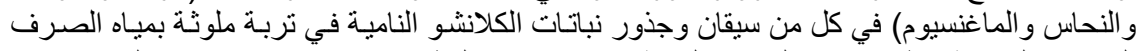

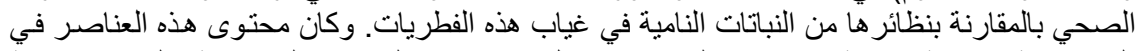

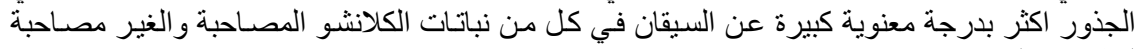
لفظريات الميكرويزا. ــ - تبين من خلال النتائج الني تم الحصول عليها إن لفطريات الجذور التكافلية دورا ايجابيا في حماية نبات

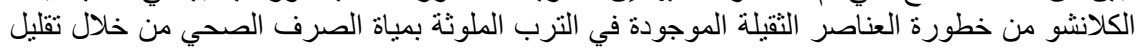

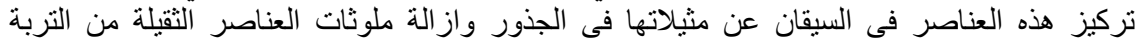

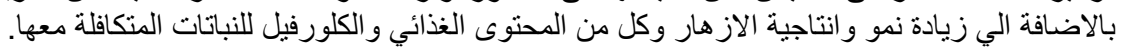

كلية الزراعة - جامعة المنصورة كلية العلوم - جامعة المنصورة - جامعة المنصوة
قام بتحكيم البحث

أ.ـد / زين العابدين عبد البد الحميد محمد

أ.د / جمال محمود عبد الفتاح عوف عبد العبد 